\title{
Evaluation of Potassium Phosphite and Myclobutanil Combinations for Pear Scab (Venturia pirina) Suppression
}

\author{
Glynn C. Percival and Kelly Noviss
}

\begin{abstract}
The purpose of this study was to investigate the use of potassium phosphite (Pi) alone and in combination with a reduced dose of synthetic fungicide (myclobutanil) to control pear scab (Venturia pirina) under field conditions. Irrespective of Pi and myclobutanil concentration, no leaf or fruit phytotoxic effects were observed throughout the 2006 and 2007 experiments. In both field experiments, Pi alone significantly reduced the incidence and severity of $V$. pirina on leaves and fruit compared to water-treated control with the degree of scab reduction similar to that of a reduced dose of myclobutanil. The efficacy of Pi at $20 \mathrm{ml}$ per liter water in inhibiting V. pirina scab incidence and severity was superior than that of Pi at 10 $\mathrm{ml}$ per liter water and a reduced dose of myclobutanil in virtually all monthly assessments. Combining a reduced dose of myclobutanil with either $\mathrm{Pi}$ at $10 \mathrm{ml}$ or $20 \mathrm{ml}$ per liter significantly improved the efficacy of scab control compared to stand alone applications of each product at most monthly assessments. Data analyzed with Limpel's formula indicated a positive synergistic effect between Pi and a reduced dose of myclobutanil. Greatest reductions in V. pirina incidence and severity on leaves and fruit were, however, achieved by stand alone applications of myclobutanil at manufacturers recommended strength. Irrespective of year, crown volume, number of fruit per tree, and total fruit yield were higher in Pi and myclobutanil treated trees irrespective of concentration applied compared to water-treated controls. A combined mix of Pi with a reduced dose of myclobutanil proved effective in increasing crown volume, number of fruit per tree and fruit yield compared to stand alone applications of each treatment. Greatest increases in crown volume, number of fruit per tree and fruit yield were achieved by applications of myclobutanil at the manufacturers recommended strength. In virtually all cases, Pi combined with a reduced dose of myclobutanil induced positive synergistic effects on crown volume and fruit yield greater than their additive effects alone. Mean fruit weight per tree were in all cases higher in Pi and myclobutanil treated trees irrespective of concentration applied compared to water-treated controls, however, these differences were not statistically significant in all cases.

Key Words. Fungicides, Integrated Disease Management; Orchard Management; Pathogen Control; Plant Health Care; Synergism; Urban Landscapes.
\end{abstract}

Pear scab caused by Venturia pirina causes significant economic losses annually in many countries where pears are grown for human consumption (Villalta et al. 2004). In addition, ornamental pear species are planted into urban landscapes (e.g., streets, public recreation areas, car parks) for aesthetics such as flowers, bark, berry, and leaf color. Repeated pear scab infection can result in tree mortality and/or undesirable reductions in aesthetic appearance. Controlling pear scab requires the frequent application of synthetic fungicides each season depending on weather conditions (Washington et al. 1999). Public demands to reduce fungicide use, stimulated by greater awareness of environmental and health issues, as well as development of fungicide tolerant strains of scab has placed greater emphasis on the development of reduced fungicide control strategies (Gozzo 2003; Fobert and Després 2005; Ilhan et al. 2006). Likewise, increased legislative restrictions regarding the registration, use and application of pesticides has led to a situation within Europe whereby more fungicides are withdrawn on an annual basis than released onto the commercial market, which in turn increases selection pressure for fungicide resistance in surviving populations (Anonymous 2009). For these reasons, research has focused on the development of a range of novel plant protection products that have limited or no known adverse effect on the environment and human health (Garbelotto et al. 2007). Pertinent examples include application of inorganic calcium and boron fertilizers, biologically inert film forming polymers, systemic inducing agents, and biostimulants (Sutherland and Walters 2002; Ippolito et al. 2005; Rolshausen and Gubler 2005; Akbudak et al. 2006; Percival et al. 2006; Percival et al. 2009). The consensus of research opinion in the majority of cases however, concludes that most of these novel plant protection products are generally less effective and consistent than standard synthetic fungicides for pathogen control (Agostini et al. 2003; Krokene et al 2008; Percival and Haynes 2008; Percival et al. 2009). This has led to the suggestion that a more appropriate role for these types of products would be in combination with a reduced dose of synthetic fungicide to achieve control comparable or significantly higher than stand alone applications of fungicides at full dose (Bécot et al. 2000; Van Loon et al. 2002; Ilhan et al. 2006). This in turn would reduce potential environmental impacts and extend the working life of existing fungicide products.

One family of potential plant protection products are inorganic potassium and phosphite salts. When applied to plants either as a foliar spray or soil drench, phosphites exhibit a complex mode of action, acting both on the pathogen (direct) and by stimulating plant host defense responses (indirect), such as: the accumulation of phytoalexins, hypersensitive cell death, cell wall lignification and fortification and formation of lytic enzymes that inhibit pathogen growth (Guest and Grant 1991; Garbelotto et al. 
2007). Research in Australia and the U.S. has found potassium phosphite salts to be extremely effective in the control of pathogens belonging to the Oomycetes group, such as Phytophthora spp., Pythium spp., and the Downy Mildew diseases (Jackson et al. 2000; Miller et al. 2006). In addition, potassium phosphite has been shown to suppress fungal pathogens that fall outside this group such as Venturia inaequalis (apple scab) (MacHardy and Jeger 1983), and bacterial diseases such as Erwinia amylovora (apple fire blight). The objective of this study was to investigate the use of potassium phosphite $(\mathrm{Pi})$ alone and in combination with a reduced dose of synthetic fungicide (myclobutanil) to control pear scab under field conditions. Within the UK, myclobutanil, a systemic, protectant, and curative triazole fungicide, is commercially registered for the control of pear scab.

\section{MATERIALS AND METHODS}

\section{Field Trials}

The pear trial site consisted of a 0.90 ha block of Pyrus communis 'Williams' Bon Chrétien' interspersed with individual trees of Pyrus communis Beth and Concorde. Pyrus communis 'Williams' Bon Chrétien' was chosen for experimental purposes due to its sensitivity to pear scab infection. Planting distances were based on $2 \mathrm{~m} \times 2 \mathrm{~m}$ spacing. The trees were planted in 2003 and trained under the central-leader system to an average height of $2.5 \mathrm{~m} \pm 0.25 \mathrm{~m}$, and with mean trunk diameters of $12 \mathrm{~cm} \pm 1.4 \mathrm{~cm}$ at $45 \mathrm{~cm}$ above the soil level. The trial site was located at the University of Reading Shinfield Experimental Site, University of Reading, Berkshire, UK $\left(51^{\circ} 43 \mathrm{~N},-1^{\circ} 08 \mathrm{~W}\right)$.

The soil was a sandy loam containing 3\%-5\% organic matter, $\mathrm{pH}$ of 6.1. Weeds were controlled chemically using glyphosate (Roundup; Green-Tech, Sweethills Park, Nun Monkton, York, UK), throughout experiments. No water, fertilizer, or plant growth regulators were applied during the two-year trial. Historically, the pears suffered from pear scab infection on an annual basis. Consequently, prior to the trial commencing in 2006 and 2007, trees were inspected in September 2005 and 2006 and only those trees with $>50 \%$ of leaves affected with pear scab infection were used in the trials. A minimal insecticide program based on the residual pyrethroid insecticide deltamethrin (product name Bandu, Headland Agrochemicals, Ltd., Saffron Walden, Essex, UK) was applied every three months during each growing season commencing in May 2006 to September 2007. All sprays were applied using a Tom Wanner Spray Rig sprayer at $40 \mathrm{ml}$ deltamethrin (Bandu) per 100 liters of water. Trees were sprayed until runoff, generally 0.35 liter insecticide per tree.

\section{Spray Treatments}

Potassium phosphite ( $\mathrm{Pi} ; 300 \mathrm{~g}$ phosphorous acid per liter water), trade name Phoenix (Orion Future Technology, Ltd., Henwood House, Henwood, Ashford, Kent, UK) and myclobutanil, trade name Systhane 20EW (Landseer, Ltd., Chelmsford, Essex, UK) sprays were applied at four growth stages identified as key treatment times for scab control under field conditions (Bevan and Knight 2001), namely: bud break (March 11, 2006; March 17, 2007), green cluster (April 1, 2006; April 7, 2007), 90\% petal fall (May 13, 2006; May 19, 2007), and early fruitlet (June 1, 2006;
June 8, 2007). Prior to spray treatments, trees were inspected and no visible symptoms of pear scab were apparent. During spray treatments polythene screens $2.5 \mathrm{~m}$ high were erected around each tree to prevent dispersal of sprays and possible cross contact with other trees. The base of the tree was covered with a $0.5 \mathrm{~m}$ $\times 0.5 \mathrm{~m}$ polythene mulch to prevent potential soil percolation.

The experimental treatments and the application protocol for the treatments were as follows:

1) water-treated control

2) Pi at $10 \mathrm{ml}$ per liter water

3) Pi at $20 \mathrm{ml}$ per liter water

4) Myclobutanil at $0.3 \mathrm{ml}$ per liter water (manufacturer's recommended strength)

5) Myclobutanil at $0.075 \mathrm{ml}$ per liter water (25\% of manufacturer's recommended strength).

6) Pi at $10 \mathrm{ml}+$ myclobutanil at $0.075 \mathrm{ml}$ per liter water.

7) $\mathrm{Pi}$ at $20 \mathrm{ml}+$ myclobutanil at $0.075 \mathrm{ml}$ per liter water.

The treatments (one water control; two Pi; two myclobutanil; two Pi + myclobutanil combinations), were applied in 10 randomized complete blocks with a single tree as the experimental unit, giving a total of 70 observations per response variable. Foliar sprays of each product were applied until runoff using a hand sprayer (Cooper Pegler, Watling Street, Clfton upon Dunsmore, UK).

\section{Scab Incidence and Severity}

The degree of protection conferred by each treatment was assessed by recording scab incidence and severity at monthly intervals from July to September.

Scab incidence: At each assessment, 100 leaves and 30 fruits were chosen arbitrarily from different sides of a tree. A leaf or a fruit was considered to be infected if at least one visible scab lesion was present.

Scab severity of leaves and fruit was assessed visually. Leaf scab severity of each tree was rated using a visual indexing technique and ratings on the scale: $0=$ No scab observed; $1=$ less than $5 \%$ of leaves affected and no aesthetic impact; $2=5 \%-20 \%$ of leaves affected with some yellowing but little or no defoliation; $3=21 \%-50 \%$ of leaves affected, significant defoliation and/or leaf yellowing; $4=$ $51 \%-80 \%$ of leaves affected, severe foliar discoloration; $5=$ $81 \%-100 \%$ of leaves affected with $90 \%-100 \%$ defoliation.

Scab severity on fruit was calculated on the following scale: $0=$ no visible lesions; $1=<10 \%$ fruit surface infected; $2=10 \%-25 \%$ fruit surface infected; $3=25 \%-50 \%$ fruit surface infected; $4=>50 \%$ fruit surface infected. Leaf scab severity ratings used in this study was based on UK and Ireland market standards for fungicide evaluation of scab control (Butt et al. 1990; Swait and Butt 1990). Fruit scab severity was based a scale used by Ilhan et al. (2006). Scab severity ratings were undertaken by three independent BASIS (British Agrochemical Standards Inspection Scheme) qualified crop protection specialists. 


\section{Fruit Yield and Crown Volume}

Mean fruit weight per tree was determined by counting the number of fruit still attached to the tree at harvest and dividing by total fruit weight per tree. Yield per tree was determined by weighing all fruit on each tree at harvest and dividing by the number of trees per treatment.

Crown volume $(\mathrm{Cv})$ was estimated from the crown width (D) and crown depth (L) using the paraboloid form of the crown (Kupka 2007):

$$
\mathrm{Cv}=\underset{8}{\prod} \frac{\mathrm{D}^{2} \mathrm{~L}}{}
$$

\section{Statistical Analysis}

Mean scab severity values for all treatments were transformed using the Arcsin $\left(\operatorname{sine}^{-1}\right)$ transformation. Analysis of variance was performed separately for each month and each year and means were separated by LSD $(P=0.05)$ following appropriate checks for homogeneity using the Genstat for Windows program. Back transformed pathogen severity values are presented here to ease interpretation of these data. Limpel's formula, as described by Richer (1987), was used to describe synergistic interactions between the reduced dose of myclobutanil and both phosphite combinations. Limpel's formula is $\mathrm{E}_{e}=A+B-(A B / 100)$ in which $\mathrm{E}_{e}$ is the expected effect from additive responses of two treatments and $A$ and $B$ are the percentages of reductions in disease incidence or severity relative to each treatment alone. Thus, if the combination of the two treatments produces any value of reduction greater than $\mathrm{E}_{e}$, then this is evidence for synergistic activity (Lorito et al. 1993).

\section{RESULTS}

Irrespective of Pi and myclobutanil concentration no leaf or fruit phytotoxic effects were observed throughout the 2006 and 2007 experiments (data not shown). In the first field experiment, conducted in 2006, Pi at $10 \mathrm{ml}$ and $20 \mathrm{ml}$ per liter of water significantly reduced the incidence and severity of $V$. pirina on both leaves and fruit compared to water-treated control (Table 1). The efficacy of Pi at $10 \mathrm{ml}$ and $20 \mathrm{ml}$ per liter water was similar to that of a reduced dose of myclobutanil $(0.075$ $\mathrm{ml})$ per liter of water in all monthly assessments from July to September. In general, the efficacy of Pi at $20 \mathrm{ml}$ per liter of water in inhibiting scab incidence and severity was superior to that of Pi at $10 \mathrm{ml}$ per liter water and a reduced dose of myclobutanil in virtually all monthly assessments. Combining Pi at $10 \mathrm{ml}$ and $20 \mathrm{ml}$ per liter of water with a reduced dose of myclobutanil in most instances significantly improved the efficacy of stand alone applications of treatments. In addition, data analyzed with Limpel's formula demonstrated synergistic effects between $\mathrm{Pi}$ at $10 \mathrm{ml}$ and $20 \mathrm{ml}$ per liter of water and a reduced dose of myclobutanil in inhibiting $V$. pirina leaf incidence and severity in July and September assessments (Table 1). Similar synergistic activity was recorded between Pi at 20 $\mathrm{ml}$ per liter of water and a reduced dose of myclobutanil in the assessments made in September with respect to $V$. pirina incidence and severity on fruit (Table 2). Greatest reductions in $V$. pirina incidence and severity on leaves and fruit were achieved by stand alone applications of myclobutanil at the manufacturers recommended strength of $0.3 \mathrm{ml}$ per liter water (Table 1).

In the second field experiment, conducted in 2007, weather conditions were more favorable and scab incidence and severity were higher than in 2006. Pi at $10 \mathrm{ml}$ and $20 \mathrm{ml}$ per liter of water and reduced dose of myclobutanil treatments were effective in reducing $V$. pirina incidence and severity on leaves in all monthly assessments from July to September; in addition, the incidence and severity on fruit was recorded at the cessation of the growing season (Table 2). Similar to the results of the experiment conducted in 2006, the efficacy of Pi at $20 \mathrm{ml}$ per liter of water in inhibiting $V$. pirina incidence and severity was superior than that of $\mathrm{Pi}$ at $10 \mathrm{ml}$ per liter of water and a reduced dose of myclobutanil at most monthly assessments. Combining $\mathrm{Pi}$ at $10 \mathrm{ml}$ and $20 \mathrm{ml}$ per liter of water with a reduced dose of myclobutanil significantly improved the efficacy of

Table 1. The efficacy of $\mathrm{Pi}$ alone or in combination with reduced dose of myclobutanil in reducing the disease incidence and

\begin{tabular}{|c|c|c|c|c|c|c|c|c|}
\hline \multirow[t]{3}{*}{ Treatments } & \multicolumn{2}{|l|}{ July 13} & \multicolumn{2}{|l|}{ August 9} & \multicolumn{2}{|c|}{ September 5} & \multicolumn{2}{|c|}{ September 5} \\
\hline & Leaves & & & & & & Fruit & \\
\hline & $\begin{array}{l}\text { Scab } \\
\text { Incidence }\end{array}$ & $\begin{array}{l}\text { Scab } \\
\text { Severity }\end{array}$ & $\begin{array}{l}\text { Scab } \\
\text { Incidence }\end{array}$ & $\begin{array}{l}\text { Scab } \\
\text { Severity }\end{array}$ & $\begin{array}{l}\text { Scab } \\
\text { Incidence }\end{array}$ & $\begin{array}{l}\text { Scab } \\
\text { Severity }\end{array}$ & $\begin{array}{l}\text { Scab } \\
\text { Incidence }\end{array}$ & $\begin{array}{l}\text { Scab } \\
\text { Severity }\end{array}$ \\
\hline Control & $26.4 \mathrm{a}$ & $1.3 \mathrm{a}$ & $43.8 \mathrm{a}$ & $2.7 \mathrm{a}$ & $51.6 \mathrm{a}$ & $3.0 \mathrm{a}$ & $50.5 \mathrm{a}$ & $2.9 \mathrm{a}$ \\
\hline Myclobutanil $0.3 \mathrm{ml}$ & $5.0 \mathrm{e}$ & $0.4 \mathrm{~d}$ & $12.8 \mathrm{c}$ & $0.5 \mathrm{~d}$ & $21.1 \mathrm{~d}$ & $0.7 \mathrm{e}$ & $18.2 \mathrm{c}$ & $0.4 \mathrm{c}$ \\
\hline $\mathrm{Pi} 10 \mathrm{ml}$ & $18.1 b$ & $1.0 \mathrm{ab}$ & $26.7 b$ & $1.8 \mathrm{~b}$ & $40.2 b$ & $2.3 b$ & $40.3 \mathrm{a}$ & $2.0 \mathrm{~b}$ \\
\hline Pi $20 \mathrm{ml}$ & $13.0 \mathrm{bcd}$ & $0.7 \mathrm{bcd}$ & $20.9 b c$ & $1.1 \mathrm{~cd}$ & $32.8 \mathrm{bc}$ & $1.6 \mathrm{~cd}$ & $33.3 b$ & $1.4 \mathrm{~b}$ \\
\hline $\begin{array}{l}\text { Pi } 10 \mathrm{ml}+ \\
\quad \text { Myclobutanil } 0.075 \mathrm{ml}\end{array}$ & $7.0 \mathrm{de}^{\mathrm{z}}$ & $0.6 \mathrm{~cd}^{\mathrm{z}}$ & $19.5 b c$ & $1.0 \mathrm{~cd}$ & $26.7 \mathrm{~cd}^{\mathrm{z}}$ & $1.8 \mathrm{bc}$ & $27.8 \mathrm{bc}$ & $1.6 \mathrm{~b}$ \\
\hline $\begin{array}{l}\text { Pi } 20 \mathrm{ml}(0.66)+ \\
\quad \text { Myclobutanil } 0.075 \mathrm{ml}\end{array}$ & $7.0 \mathrm{de}^{\mathrm{z}}$ & $0.4 \mathrm{~d}^{\mathrm{z}}$ & $14.3 \mathrm{c}$ & $0.8 \mathrm{~cd}$ & $24.1 \mathrm{~cd}$ & $1.0 \mathrm{de}^{\mathrm{z}}$ & $20.3 \mathrm{c}^{\mathrm{z}}$ & $0.6 \mathrm{c}^{\mathrm{z}}$ \\
\hline LSD & 6.4 & 0.30 & 12.3 & 0.62 & 11.3 & 0.62 & 10.8 & 0.6 \\
\hline
\end{tabular}
severity on leaves and fruit caused by Venturia pirina in 2006.

${ }^{z}$ Synergistic effect according to Limpel's formula

Scab incidence $=$ total number of fruit and leaves with scab symptoms/number of leaves (100) and fruit (30) examined. Lower case letters indicate significant differences between means for each evaluation date by $\operatorname{LSD}(P=0.05)$. All treatments applied per liter of water. All values mean of ten trees, 100 leaves and 30 fruits per tree. Leaf scab severity scale: $0=$ No scab observed; $1=$ less than $5 \%$ of leaves affected and no aesthetic impact; $2=5 \%-20 \%$ of leaves affected with some yellowing but little or no defoliation; $3=21 \%-50 \%$ of leaves affected, significant defoliation and/or leaf yellowing; $4=51 \%-80 \%$ of leaves affected, severe foliar discoloration; $5=81 \%-100 \%$ of leaves affected with $90 \%-100 \%$ defoliation.

Fruit scab severity scale: $0=$ no visible lesions; $1=<10 \%$ fruit surface infected; $2=10 \%-25 \%$ fruit surface infected; $3=25 \%-50 \%$ fruit surface infected; $4=>50 \%$ fruit surface infected. 
stand alone applications of treatments. According to Limpel's formula, a number of synergistic effects between $\mathrm{Pi}$ at $10 \mathrm{ml}$ and $20 \mathrm{ml}$ per liter of water and a reduced dose of myclobutanil were found to reduce scab incidence in the July (Pi at $10 \mathrm{ml}$ liter only) and September assessments on both leaf and fruit (Pi at $10 \mathrm{ml}$ and $20 \mathrm{ml}$ per liter; Table 2). Similar to the 2006 trial maximal reductions in $V$. pirina, incidence and severity on leaves and fruit was achieved by stand alone applications of myclobutanil at manufacturers recommended strength (Table 2).

Irrespective of year, the crown volume, number of fruit per tree, and fruit yield were higher in $\mathrm{Pi}$ and myclobutanil treated trees in all cases, irrespective of concentration applied in comparison with water-treated controls. Application of Pi at $10 \mathrm{ml}$ and $20 \mathrm{ml}$ per liter water proved more effective in increasing crown volume, number of fruit per tree, and fruit yield than that of a reduced dose of myclobutanil. However, a com- bined mix of $\mathrm{Pi}$ at $10 \mathrm{ml}$ and $20 \mathrm{ml}$ per liter of water with a reduced dose of myclobutanil proved effective in further increasing crown volume, number of fruit per tree, and fruit yield compared to stand alone applications of each treatment. Greatest increases in crown volume, number of fruit per tree, and fruit yield were achieved by applications of myclobutanil at the manufacturers recommended dose. In all cases except one, fruit yield in September 2007 following a Pi $20 \mathrm{ml}$ per liter of water and reduced dose of myclobutanil, Pi and a reduced dose of myclobutanil combination induced synergistic effects on crown volume and fruit yield greater than their additive effects alone based on Limpel's equation. Irrespective of year, mean fruit weight per tree were in all cases higher in $\mathrm{Pi}$ and myclobutanil treated trees irrespective of concentration applied compared to water-treated controls; however, in most cases these differences were not statistically significant.

Table 2. The efficacy of $\mathrm{Pi}$ alone or in combination with reduced dose of myclobutanil in reducing the disease incidence and severity on leaves and fruit caused by Venturia pirina in 2007.

\begin{tabular}{|c|c|c|c|c|c|c|c|c|}
\hline \multirow[t]{3}{*}{ Treatments } & \multicolumn{2}{|l|}{ July 9} & \multicolumn{2}{|l|}{ August 1} & \multicolumn{2}{|c|}{ September 9} & \multicolumn{2}{|c|}{ September 9} \\
\hline & Leaves & & & & & & Fruit & \\
\hline & $\begin{array}{l}\text { Scab } \\
\text { Incidence }\end{array}$ & $\begin{array}{l}\text { Scab } \\
\text { Severity }\end{array}$ & $\begin{array}{l}\text { Scab } \\
\text { Incidence }\end{array}$ & $\begin{array}{l}\text { Scab } \\
\text { Severity }\end{array}$ & $\begin{array}{l}\text { Scab } \\
\text { Incidence }\end{array}$ & $\begin{array}{l}\text { Scab } \\
\text { Severity }\end{array}$ & $\begin{array}{l}\text { Scab } \\
\text { Incidence }\end{array}$ & $\begin{array}{l}\text { Scab } \\
\text { Severity }\end{array}$ \\
\hline Control & $33.0 \mathrm{a}$ & $1.7 \mathrm{a}$ & $54.6 \mathrm{a}$ & $3.0 \mathrm{a}$ & $63.8 \mathrm{a}$ & $3.2 \mathrm{a}$ & $43.8 \mathrm{a}$ & $2.3 \mathrm{a}$ \\
\hline Myclobutanil $0.3 \mathrm{ml}$ & $9.0 \mathrm{e}$ & $0.6 \mathrm{~d}$ & $18.0 \mathrm{c}$ & $0.9 \mathrm{~d}$ & $28.1 \mathrm{c}$ & $1.0 \mathrm{e}$ & $20.7 d$ & $0.7 \mathrm{~d}$ \\
\hline Pi $10 \mathrm{ml}$ & $23.7 \mathrm{~b}$ & $1.3 \mathrm{ab}$ & $35.9 \mathrm{~b}$ & $2.1 \mathrm{~b}$ & $44.7 b$ & $2.7 \mathrm{ab}$ & $31.7 \mathrm{~b}$ & $1.9 \mathrm{ab}$ \\
\hline Pi $20 \mathrm{ml}$ & $18.5 \mathrm{bcd}$ & $0.9 \mathrm{bcd}$ & $27.0 \mathrm{bc}$ & $1.6 \mathrm{bc}$ & $37.9 \mathrm{bc}$ & $1.9 \mathrm{~cd}$ & $28.4 \mathrm{bc}$ & $1.4 \mathrm{bc}$ \\
\hline $\begin{array}{l}\text { Pi } 10 \mathrm{ml}+ \\
\quad \text { Myclobutanil } 0.075 \mathrm{ml}\end{array}$ & $12.4 \mathrm{de}^{2}$ & $1.1 \mathrm{bc}$ & $24.5 b c$ & $1.8 \mathrm{bc}$ & $33.6 \mathrm{bc}$ & $2.0 \mathrm{c}^{2}$ & $23.8 \mathrm{bcd}$ & $1.4 \mathrm{bc}^{2}$ \\
\hline $\begin{array}{l}\text { Pi } 20 \mathrm{ml}+ \\
\quad \text { Myclobutanil } 0.075 \mathrm{ml}\end{array}$ & $13.8 \mathrm{cde}$ & $0.8 \mathrm{~cd}$ & $22.0 \mathrm{c}$ & $1.3 \mathrm{~cd}$ & $31.4 \mathrm{bc}$ & $1.4 \mathrm{de}^{\mathrm{z}}$ & $21.4 \mathrm{~cd}$ & $1.1 \mathrm{~cd}$ \\
\hline LSD & 6.9 & 0.4 & 12.5 & 0.6 & 15.1 & 0.5 & 8.2 & 0.5 \\
\hline
\end{tabular}

${ }^{2}$ Synergistic effect according to Limpel's formula.

Scab incidence $=$ total number of fruit and leaves with scab symptoms/number of leaves (100) and fruit (30) examined. Lower case letters indicate significant differences between means for each evaluation date by LSD $(P=0.05)$. All treatments applied per liter of water. All values mean of ten trees, 100 leaves and 30 fruits per tree.

Leaf scab severity scale: $0=$ No scab observed; $1=$ less than $5 \%$ of leaves affected and no aesthetic impact; $2=5 \%-20 \%$ of leaves affected with some yellowing but little or no defoliation; $3=21 \%-50 \%$ of leaves affected, significant defoliation and/or leaf yellowing; $4=51 \%-80 \%$ of leaves affected, severe foliar discoloration; $5=81 \%-100 \%$ of leaves affected with $90 \%-100 \%$ defoliation.

Fruit scab severity scale: $0=$ no visible lesions; $1=<10 \%$ fruit surface infected; $2=10 \%-25 \%$ fruit surface infected; $3=25 \%-50 \%$ fruit surface infected; $4=>50 \%$ fruit surface infected.

Table 3. The efficacy of $\mathrm{Pi}$ alone or in combination with reduced dose of myclobutanil on growth of pear (Pyrus communis 'Williams' Bon Chrétien') at the cessation of the growing season.

\begin{tabular}{|c|c|c|c|c|c|c|c|c|}
\hline \multirow[t]{2}{*}{ Treatment } & \multicolumn{4}{|l|}{2006} & \multicolumn{4}{|l|}{2007} \\
\hline & $\begin{array}{l}\text { Crown } \\
\text { volume }\end{array}$ & $\begin{array}{l}\text { Number } \\
\text { fruit } \\
\text { per tree }\end{array}$ & $\begin{array}{l}\text { Mean fruit } \\
\text { weight }(\mathrm{g}) \\
\text { per tree }\end{array}$ & $\begin{array}{l}\text { Yield/tree } \\
(\mathrm{kg})\end{array}$ & $\begin{array}{l}\text { Crown } \\
\text { volume }\end{array}$ & $\begin{array}{l}\text { Number } \\
\text { fruit } \\
\text { per tree }\end{array}$ & $\begin{array}{l}\text { Mean fruit } \\
\text { weight }(\mathrm{g}) \\
\text { per tree }\end{array}$ & $\begin{array}{l}\text { Yield/tree } \\
(\mathrm{kg})\end{array}$ \\
\hline Control & $0.63 a$ & $38 \mathrm{a}$ & $236.8 \mathrm{a}$ & $9.0 \mathrm{a}$ & $0.66 \mathrm{a}$ & $40 a$ & $205.0 \mathrm{a}$ & $8.2 \mathrm{a}$ \\
\hline Myclobutanil $0.3 \mathrm{ml}$ & $1.40 \mathrm{e}$ & $55 \mathrm{~d}$ & $261.8 b$ & $14.4 \mathrm{c}$ & $1.51 \mathrm{c}$ & $75 d$ & $213.4 \mathrm{ab}$ & $16.0 \mathrm{~d}$ \\
\hline $\mathrm{Pi} 10 \mathrm{ml}$ & $0.89 \mathrm{bc}$ & $42 \mathrm{ab}$ & $240.4 \mathrm{a}$ & $10.1 \mathrm{ab}$ & $0.95 b$ & $51 b$ & $219.6 \mathrm{ab}$ & $11.2 b$ \\
\hline Pi $20 \mathrm{ml}$ & $0.92 b c$ & $44 \mathrm{bc}$ & $240.9 \mathrm{ab}$ & $10.6 a b$ & $0.98 b$ & $57 \mathrm{bc}$ & $228.1 b$ & $13.0 \mathrm{bc}$ \\
\hline Myclobutanil $0.075 \mathrm{ml}$ & $0.79 \mathrm{ab}$ & $40 \mathrm{ab}$ & $247.5 \mathrm{ab}$ & $9.9 \mathrm{ab}$ & $0.74 \mathrm{a}$ & $49 b$ & $218.3 \mathrm{ab}$ & $10.7 \mathrm{ab}$ \\
\hline $\begin{array}{l}\text { Pi } 10 \mathrm{ml}+ \\
\quad \text { Myclobutanil } 0.075 \mathrm{ml}\end{array}$ & $1.09 \mathrm{~cd}^{2}$ & $46 c$ & $250.0 \mathrm{ab}$ & $11.5 \mathrm{ab}^{\mathrm{z}}$ & $1.14 b^{z}$ & $60 c$ & $208.3 \mathrm{ab}$ & $12.5 b c$ \\
\hline $\begin{array}{l}\text { Pi } 20 \mathrm{ml}+ \\
\quad \text { Myclobutanil } 0.075 \mathrm{ml}\end{array}$ & $1.22 \mathrm{de}^{\mathrm{z}}$ & $48 \mathrm{c}$ & $243.8 \mathrm{ab}$ & $11.7 b^{2}$ & $1.36 \mathrm{c}^{\mathrm{z}}$ & $65 \mathrm{c}$ & $215.4 \mathrm{ab}$ & $14.0 \mathrm{~cd}^{\mathrm{z}}$ \\
\hline LSD & 0.21 & 5.7 & 21.23 & 2.5 & 0.19 & 8.2 & 22.6 & 2.7 \\
\hline
\end{tabular}

${ }^{\mathrm{z}}$ Synergistic effect according to Limpel's formula.

Means within columns with unlike letters differ significantly according to LSD $(P=0.05)$. All treatments applied per liter of water. All values mean of ten trees. Lower case letters indicate significant differences between means for each evaluation date by $\operatorname{LSD}(P=0.05)$ 


\section{DISCUSSION}

Results of this study demonstrated that $\mathrm{Pi}$ at $10 \mathrm{ml}$ and 20 $\mathrm{ml}$ per liter of water applied at four growth stages (bud break; green cluster; $90 \%$ petal fall; early fruitlet) under field conditions significantly reduced the incidence and severity of pear scab. Previous studies have reported that application of Pi to be extremely effective in the management of pathogens, particularly those that belong to the Oomycetes group such as Phytophthora citricola, $P$. capsici, $P$. infestans, Peronosclerospora sorghi, Peronospora parasitica in several economically important food crops to include potato, maize, pepper, and crucifers (Ouimette and Coffey 1989; Jackson et al. 2000; Wilkinson et al. 2001; Miller et al. 2006). In addition, phosphite application reduced pathogen severity of several powdery mildews to include Sphaerotheca fuliginea (cucumber powdery mildew), grape powdery mildew, nectarine, and mango powdery mildew (Bécot et al. 2000), as well as suppress the bacterial pathogen Pseudomonas syringae pv. syringae (pear blast) (Moragrega et al. 1998). Within Australia, phosphites are now extensively used for the control of Phytophthora cinnamomi in avocados, Downy Mildew (Plasmopara viticola) in grapevines, and Phytophthora cinnamomi and P. parasitica (heart rot) in pineapples. However, to the best knowledge of the authors of the present study, this is the first report of the efficacy of $\mathrm{Pi}$ against $V$. pirina.

In the two field experiments conducted on Pyrus communis 'Williams' Bon Chrétien', a highly sensitive pear scab variety, applications of Pi at $20 \mathrm{ml}$ per liter of water significantly and consistently reduced pear scab incidence and severity on leaves and fruit to a greater degree than $\mathrm{Pi}$ applied at $10 \mathrm{ml}$ per liter of water. Such a response was recorded even when greater conditions of rainfall were more conducive for scab development in 2007. Manufacturers recommend a $10 \mathrm{ml}$ per liter dose of $\mathrm{Pi}$ for pathogen suppression and/or stimulation of plant vitality. Results of this study indicate an increase in $\mathrm{Pi}$ concentration to $20 \mathrm{ml}$ per liter of water can achieve a greater degree of scab reduction without phytotoxicity symptoms developing on leaves or fruit. In addition, Pi at this higher concentration resulted in a greater fruit yield and crown volume compared to $\mathrm{Pi}$ applied at $10 \mathrm{ml}$ per liter of water and stand alone applications of a reduced dose of myclobutanil.

The combined effects of $\mathrm{Pi}$ at $10 \mathrm{ml}$ and $20 \mathrm{ml}$ per liter of water with a reduced dose of myclobutanil were more than their additive properties according to Limpel's formula. Pi and a reduced rate of myclobutanil acted synergistically in both the July and September assessments to reduce V. pirina incidence and severity. Such synergistic effects were particularly pronounced with respect to crown volume and fruit yield recorded in September 2006 and 2007. Consequently, combining Pi's with higher concentrations than the reduced dose of myclobutanil used in this study may result in even greater synergistic activity. Such a hypothesis is given credence by the fact that myclobutanil applied at full strength at bud break, green cluster, petal fall, and early fruitlet formation proved the most effective treatment for pear scab control. Under these circumstances leaf and fruit scab severity was reduced by $75 \%-85 \%$. Such a result is comparable with other workers following similar spray regimes [i.e., four times between flower bud formation to initial early fruit set (Butt et al. 1990; Swait and Butt 1990; Bevan and Knight 2001). Within the UK, total scab control is generally achieved via a minimum of 10-12 fungicide sprays throughout the growing season (Butt et al. 1990; Swait and Butt 1990)].

Irrespective of year, the crown volume, number of fruit per tree, and fruit yield were in all cases higher in $\mathrm{Pi}$ and myclobutanil treated trees irrespective of concentration applied compared to water-treated controls. However, little effects on mean fruit weight per tree were recorded. Detrimental effects of scab infection include premature fruit drop and reduction in fruit size (Agrios 2004; Villalta et al. 2004). Results of this investigation indicate reductions in fruit yield were caused by scab-induced fruit drop rather than specific reductions in individual fruit size. Such a response may be related to source-sink relationships. Scab induced premature fruit drop would mean the smaller remaining number of fruit having a greater sink strength that in turn would account for their comparable mean weight compared to Pi and myclobutanil-treated trees (Blanke 2007).

From a commercial aspect, producers, suppliers and vendors of pears adopt a zero tolerance policy toward pear scab on fruit (Butt et al. 1990). Consequently, to reduce scab levels to commercially accepted standards, several follow-up fungicide sprays would need to be applied. However, where fruit produce is sold under a naturally produced label within the UK, scab severity levels tend to be less stringent (Bevan and Knight 2001). Likewise, ornamental pears are grown and planted for aesthetic reasons within town and city landscapes where lower scab levels are acceptable (Percival and Haynes 2008). In these instances, Pi application can possibly be used alone or in rotation with synthetic fungicides as part of an IPM strategy.

In conclusion, results of this study indicate that application of $\mathrm{Pi}$ alone is useful in reducing the incidence and severity of pear scab. Combination of Pi with a reduced dose of myclobutanil, however, significantly improved the efficacy compared to stand alone applications of each product to further reduce the incidence and severity of pear scab on leaves and fruit. Such a response indicates that $\mathrm{Pi}$ and myclobutanil combinations offer potential to reduce the risk of fungicide resistant strains of scab developing by decreasing fungicide selection pressure. This is based on the fact that higher degrees of scab control were achieved with lower myclobutanil inputs when combined with Pi. These findings would be useful to arborists as they indicate synthetic fungicide usage can be reduced yet achieve control comparable or significantly higher than stand alone applications of fungicides at full dose. This in turn promotes a greater awareness of environmental and health issues to the public and government legislative bodies. Likewise phosphites cost in general $40 \%-80 \%$ less than conventional fungicides. Further research is ongoing evaluating $\mathrm{Pi}$ combinations with higher doses of myclobutanil and other forms of synthetic fungicides.

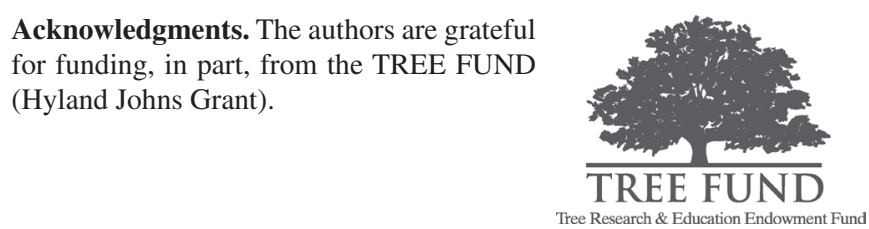




\section{LITERATURE CITED}

Agostini, J.P., P.M. Bushong, and L.W. Timmer. 2003. Glasshouse evaluation of products that induce host resistance for control of scab, melanose, and Alternaria brown spot of citrus. Plant Disease 87(1):69-75.

Agrios, G.N. 2004. Plant Pathology. 5th ed. San Diego, Academic Press.

Akbudak N., H. Tezcan, B. Akbudak, and V. Seniz. 2006. Effect of harpin protein on plant growth parameters, leaf chlorophyll, leaf colour and percentage rotten fruit of pepper plants inoculated with Botrytis cinerea. Scientia Horticulturae 109(2):107-112.

Anonymous, 2009. The UK Pesticide Guide. British Crop Protection Council, Cabi Publishing, Oxon, UK.

Bécot, S., E. Pajot, D. Le Corre, C. Monot, and C. Silué. 2000. Phytogard $\left(\mathrm{K}_{2} \mathrm{HPO}_{3}\right)$ induces localized resistance in cauliflower to downy mildew of crucifers. Crop Protection 19:417-425.

Bevan, J., and S. Knight. 2001. Organic Apple Production. 1st ed. HDRA, Emmerson Press. Kenilworth, UK.

Blanke, M.M., 2007. Regulatory mechanisms in source sink relationships in plants - A review. ISHS Acta Horticulturae 835: International Symposium on Source-Sink Relationships in Plants.

Butt, D.J., A.A.J. Swait, and J.D. Robinson. 1990. Evaluation of fungicides against apple powdery mildew and scab. Tests of Agrochemicals and Cultivars 11. Annals Applied Biology (supp) 116:34-35.

Fobert, P.R., and C. Després. 2005. Redox control of systemic acquired resistance. Current Opinion Plant Biology 8:378-382.

Garbelotto, M., D.J. Schmidt, and T.Y. Harnik. 2007. Phosphite injections and bark application of phosphite and pentra-bark control sudden oak death in coast live oak. Arboriculture \& Urban Forestry 33:309-317.

Gozzo, F., 2003. Systemic Acquired Resistance in Crop Protection: From Nature to a Chemical Approach. Journal Agricultural Food Chemistry 51:4487-4503.

Guest, D., and B. Grant. 1991. The complex action of phosphonates as antifungal agents. Biological Reviews 66:159-187.

Ilhan, K., U. Arslan, and O.A. Karabulut. 2006. The effect of sodium bicarbonate alone or in combination with a reduced dose of tebuconazole on the control of apple scab. Crop Protection 25:963-967.

Ippolito, A., L. Schena, I. Pentimone, and F. Nigro. 2005. Control of postharvest rots of sweet cherries by pre-and postharvest applications of Aureobasidium pullulans in combination with calcium chloride or sodium bicarbonate. Postharvest Biology and Technology 36:245-252.

Jackson, T.J., T. Burgess, I. Colquhoun, and G.E. St J. Hardy. 2000. Action of the fungicide phosphite on Eucalyptus marginata inoculated with Phytophthora cinnamomi. Plant Pathology 49:147-154.

Krokene, P., N.E. Nagy, and H. Solheim. 2008. Methyl jasmonate and oxalic acid treatment of Norway spruce: anatomically based defense responses and increased resistance against fungal infection. Tree Physiology 28:29-35.

Kupka, I. 2007. Growth reaction of young wild cherry (Prunus avium L.) trees to pruning. Jounal of Forest Science 53:555-560.

Lorito, M., A. Di Pietro, C.K. Hayes, S.L. Woo, and G.E. Harman. 1993. Antifungal, synergistic interactions between chitinolytic enzymes from Trichoderma harzianum and Enterobacter cloacae. Phytopathology 83:721-728.

MacHardy, W.E., and M.J. Jeger. 1983. Integrating control measures for the management of primary apple scab. Protection Ecology 5:103-125.

Miller, J.S., N. Olson, L. Woodell, L.D. Porter, and S. Clayson. 2006. Post-harvest applications of zoxamide and phosphite for control of potato tuber rots caused by oomycetes at harvest. American Journal of Potato Research 83:269-278.
Moragrega, C., Manceau, and E. Montesinos. 1998. Evaluation of soil drench treatments with phosphonate derivatives against Pseudomonas syringae pv. syringae on pear under controlled environmental conditions. European Journal of Plant Pathology 104:171-180.

Ouimette, D.G., and M.D. Coffey. 1989. Quantitative analysis of organic phosphomates, phosphonate and other inorganic anions in plant and soil using performance ion chromatography. Phytopathology 78:1150-1155.

Percival, G.C., I.P. Keary, and K. Marshall. 2006. The use of film forming polymers to control Guignardia leaf blotch and powdery mildew on Aesculus hippocastanum L. and Quercus robur L. Arboriculture \& Urban Forestry 32(3):100-108.

Percival, G.C., and I. Haynes. 2008. The influence of systemic inducing resistance chemicals for the control of oak powdery mildew (Microsphaera alphitoides) applied as a theraputic treatment. Arboriculture \& Urban Forestry 34:191-200.

Percival, G.C., K. Noviss, and I. Haynes. 2009. Field evaluation of systemic inducing resistance chemicals at different growth stages for the control of apple (Venturia inaequalis) and pear ( $V$. pirina) scab. Crop Protection 28:629-633.

Richer, D.L. 1987. Synergism: a patent view. Pesticide Science 19:309-315.

Rolshausen, P.E., and W.D. Gubler. 2005. Use of boron for the control of Eutypa dieback of grapevines. Plant Disease 89:734-738

Sutherland, F., and D.R. Walters. 2002. Effect of film forming polymers on infection of barley with the powdery mildew fungus, Bulmeria graminis f. sp. hordei. European Journal of Plant Pathology 108:385-389.

Swait, A.A.J., and D.J. Butt. 1990. Fungicides as antisporulants against apple powdery mildew and scab. Tests of Agrochemicals and Cultivars 11. Annals Applied Biology (supplement) 116:36-37.

Van Loon, L.C., P.J. Bart, G. Huub, and J.M. Linthorst. 2002. Ethylene as a modulator of disease resistance in plants. Trends in Plant Science. 11:184-191.

Villalta, O.N., W.S. Washington, and G. McGregor. 2004. Susceptibility of European and Asian pears to pear scab. Plant Protection Quarterly 19:2-4.

Washington, W.S., O. Villalta, and M. Appleby. 1998. Control of pear scab with hydrated lime alone or in schedules with other fungicide sprays. Crop Protection 17:569-580.

Wilkinson, C.J., B.L. Shearer, T.J. Jackson, and G.E. St J. Hardy. 2001. Variation in sensitivity of Western Australian isolates of Phytophthora cinnamomi to phosphite in vitro. Plant Pathology 50:83-89.

Glynn C Percival (corresponding author)

Plant Physiologist/Technical Support Specialist

R.A. Bartlett Tree Research Laboratory, Europe

The University of Reading

2 Early Gate, Whiteknights

Reading, RG6 6AU, United Kingdom

gpercival@bartlettuk.com

Kelly Noviss

Research Technician

R.A. Bartlett Tree Research Laboratory, Europe

The University of Reading

2 Early Gate, Whiteknights

Reading, RG6 6AU, United Kingdom

knoviss@bartlettuk.com 
Résumé. Le but de cette étude était de vérifier l'emploi du phosphite de potassium $(\mathrm{Pi})$ seul et de sa combinaison avec une dose réduite de fongicide synthétique (myclobutanil) pour contrôler la tavelure du poirier (Venturia pirina) sur le terrain. Indépendamment de la concentration en Pi et en myclobutanil, aucun effet phytotoxique n'a été observé durant les années expérimentales 2006 et 2007. Dans les deux expériences sur le terrain, le Pi à lui seul a permis de diminuer significativement l'incidence et la sévérité de Venturia pirina sur les feuilles et les fruits comparativement aux arbres du groupe témoin traités avec de l'eau, et ce avec des degrés de réduction de la tavelure similaires à ceux obtenus avec une dose réduite de mycolbutanil. L'efficacité du Pi à $20 \mathrm{~mL} / \mathrm{L}$ d'eau pour inhiber l'incidence et la sévérité de la tavelure par $V$. pirina était supérieure à celle du $\mathrm{Pi}$ à $10 \mathrm{~mL} / \mathrm{L}$ d'eau et du myclobutanil à dose réduite, et ce durant virtuellement tous les mois de l'évaluation. La combinaison d'une dose réduite de myclobutanil avec du Pi à 10 ou $20 \mathrm{~mL} / \mathrm{L}$ d'eau a permis de significativement améliorer l'efficacité du contrôle de la tavelure comparativement à des applications seules de l'un ou l'autre des traitements, et ce lors de la plupart des mois durant la période d'évaluation. Les données analysées au moyen d'une formule de Limpel ont indiqué une synergie positive de l'effet entre le Pi et une dose réduite de myclobutanil. Les plus grandes diminutions de l'incidence et de la sévérité de $V$. pirina sur les feuilles et les fruits étaient néanmoins obtenues par des applications seules de myclobutanil selon la posologie recommandée par le fabricant. Indépendamment de l'année, le volume de cime, le nombre de fruits par arbre et la quantité de fruits produits étaient plus élevés avec les arbres traités avec le Pi et le myclobutanil, et ce peu importe la concentration de l'application, comparativement aux arbres du groupe témoin traités avec de l'eau. Le mélange combiné de Pi avec une dose réduite de myclobutanil a prouvé son efficacité pour accroître le volume de cime, le nombre de fruits par arbre et la quantité de fruits produits comparativement à des applications seules de l'un ou l'autre de ces produits. Le plus grand accroissement en volume de cime, en nombre de fruits et en quantité de fruits produits a été obtenu avec des applications de myclobutanil selon le dosage recommandé par le fabricant. Dans pratiquement tous les cas, le Pi combiné avec une dose réduite de myclobutanil a induit des effets synergiques positifs sur le volume de cime et la production de fruits qui étaient plus grands que les effets additionnés seuls à seuls. La masse moyenne par fruit était dans tous les cas plus élevée avec les arbres traités avec le Pi ou le myclobutanil, et ce indépendamment de la concentration des applications, comparativement aux arbres du groupe témoin traités avec de l'eau; néanmoins, ces différences n'étaient statistiquement pas significatives dans tous les cas.

Zusammenfassung. Die Absicht dieser Studie bestand darin, den Gebrauch von Kaliumphosphit allein und in Kombination mit einer reduzierten Dosis von einem systemischen Fungizid (Myclobutanil) zur Kontrolle von Birnenschorf unter Feldbedingungen zu untersuchen. Unabhängig von den Kaliumphosphit- und Myclobutanil-Konzentrationen konnten während der Feldexperimente in 2006 und 2007 keine phytotoxischen Effekte auf den Blättern oder Füchten beobachtet werden. In beiden Feldexperimenten konnte Kaliumphosphit allein den Befall mit Birnenschorf auf Blättern und Früchten im Vergleich mit einer Wasserbehandelten Kontrolle auf den Befallslevel reduzieren, der bei einer reduzierten Gabe des Fungizids ebenfalls erreicht wurde. Die Wirksamkeit von Kaliumphosphit bei $20 \mathrm{ml} / \mathrm{l}$ Wasser bei der Hemmung von Birnenschorfvorkommen und hohem Befallsgrad war starker als bei $10 \mathrm{ml} / \mathrm{l}$ Wasser und einer reduzierten Gabe von Myclobutanil in allen monatlichen Überprüfungen. Die Kombination von einer reduzierten Gabe von Myclobutanil mit Kaliumphosphit in 10 oder $20 \mathrm{ml} / \mathrm{l}$ verbesserte deutlich die Wirksamkeit der Birnenschorfkontrolle, verglichen mit alleinigen
Applikationen von jedem Produkt bei den meisten monatlichen Überprüfungen. Eine Datenanalyse mit der Limpel-Formel zeigte einen positiven Synergie-Effekt zwischen Kaliumphosphit und einer reduzierten Gabe von Myclobutanil. Die größten Reduktionen von Birnenschorf-Vorkommen und Befallsstärke auf den Blättern und Früchten werden bei alleinigen Gaben von Myclobutanil in Applikationen gemäss der Herstellerangaben erzielt. Unabhängig vom Jahr waren das Kronenvolumen, die Anzahl der Früchte pro Baum und der Fruchtertrag höher bei Bäumen, die mit Kaliumphosphit und Myclobutanil behandelt wurden, unabhängig von der verwendeten Konzentration und im Vergleich zur wasserbehandelten Kontrolle. Eine kombinierte Mischung aus Kaliumphosphit und einer reduzierten Myclobutanilgabe zeigte sich effektiv durch ansteigendes Kronenvolumen, Anzahl der Früchte pro Baum und Fruchtertrag im Vergleich zu Einzelgaben. Der größte Anstieg bei Kronenvolumen, Anzahl der Früchte pro Baum und Fruchtertrag wurde erreicht durch die Applikation von Myclobutanil gemäss der Herstellerangaben. In allen Fällen führte die Kombination von Kaliumphosphit und einer reduzierten Myclobutanilgabe zu positiveren Synergieeffekten bei Kronenvolumen, Anzahl der Früchte pro Baum und Fruchtertrag als ihre addierten Einzelergebnisse. Das durchschnittliche Fruchtgewicht pro Baum war in allen Fällen höher als bei mit Kaliumphosphit und Myclobutanil behandelten Bäumen, unabhängig von der applizierten Konzentration im Vergleich zu den wasserbehandelten Kontrollen, obwohl diese Unterschiede in allen Fällen statistisch nicht relevant waren.

Resumen. El propósito del estudio fue investigar el uso del fosfito de potasio $(\mathrm{Pi})$, solo y en combinación con una dosis reducida de fungicida sintético (myclobutanil), para controlar la costra de la pera (Venturia pirina) bajo condiciones de campo. Sin contar la concentración de Pi y myclobutanil, no fueron observados efectos de fitotoxicidad en la hoja y el fruto a través de los experimentos de 2006 y 2007. En ambos experimentos de campo, Pi solo redujo significativamente la incidencia y severidad de V. pirina en hojas y fruto, comparado con controles tratados con agua con el grado de reducción similar de la costra a una dosis reducida de myclobutanil. La eficacia de Pi a $20 \mathrm{ml}(0.66 \mathrm{fl} \mathrm{oz})$ por litro $(0.26$ gal) de agua en la inhibición de la incidencia y severidad de la costra $V$. pirina fue superior que $\mathrm{Pi}$ a $10 \mathrm{ml}(0.33 \mathrm{fl} \mathrm{oz})$ por litro de agua y una dosis reducida de myclobutanil virtualmente en todos los meses de medición. Los datos analizados con la fórmula de Limpel indicaron un efecto sinérgico positivo entre Pi y una dosis reducida de myclobutanil. Las mayores reducciones en la incidencia y severidad de $V$. pirina en las hojas y frutos fueron, sin embargo, alcanzadas por aplicaciones solo de myclobutanil a las resistencias recomendadas por los fabricantes. Sin contar el año, el volumen de la copa, número de frutos por árbol, y total de rendimiento de frutas fueron mayores en árboles tratados con $\mathrm{Pi}$ y myclobutanil, sin tener en cuenta la concentración aplicada comparada con controles con agua. Una mezcla combinada de Pi con una dosis reducida de myclobutanil proporciona un efectivo y gran volumen de copa, número de frutos por árbol y rendimiento de frutos comparados con aplicaciones solas de cada tratamiento. Los mayores incrementos en volumen de copa, número de frutos por año y rendimiento fueron alcanzados con aplicaciones de myclobutanil. En virtualmente todos los casos Pi combinado con un dosis reducida de myclobutanil indujo efectos sinérgicos positivos en volumen de copa y rendimiento de frutas mayores que solamente sus efectos aditivos. La media del peso de frutos por árbol fue en todos los casos mayor en árboles tratados con Pi y myclobutanil sin contar las concentraciones aplicadas comparadas con controles con agua, sin embargo, estas diferencias no fueron estadísticamente significativas en todos los casos. 